\title{
DETERMINATION OF THE COST COMPONENT IN THE SOCIAL COST-BENEFIT ANALYSIS OF ROAD PROJECTS IN SOUTH AFRICA
}

\author{
W.J. Pienaar ${ }^{1 *}$
}

\section{ARTICLE INFO}

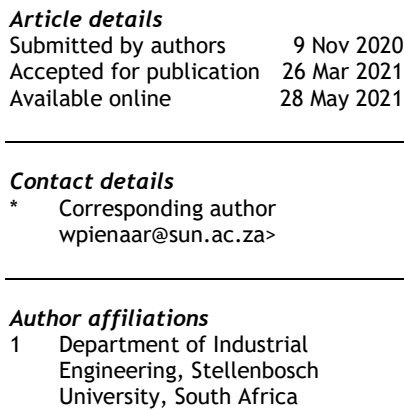

\section{ORCID® identifiers}

W. Pienaar

https: / /orcid.org/0000-0002-3638-1111

DOI

http://dx.doi.org/10.7166/32-1-2460

\section{ABSTRACT}

The article deals with the preferred approach to determine the cost component in the social cost-benefit analysis (SCBA) of road projects in South Africa. The article is in four parts. The first part, the introduction, provides the reasons why investment cost should be identified as a single cost entity in the SCBA of a road project, regardless of the criteria according to which a project is adjudicated. The second part discusses the principles that guide the determination of the social opportunity costs (SOC) of road projects. The third part identifies the two items that form the cost component of the SCBA of road projects; the SOC of (i) the land required to accommodate the road reserve, and (ii) the construction of the road. The cost component of the latter is sub-divided into labour, plant, equipment, fuel, materials, and normal profit. The section also details a recommended procedure to convert the financial budget of a road construction project to an estimate of its SOC. The fourth section draws some conclusions from the study.

\section{OPSOMMING}

Die artikel sit die werkwyse uiteen wat aanbeveel word om die kostekomponent in die sosiale koste-voordeel-ontleding (SKVO) van padprojekte in Suid-Afrika te bepaal. Die aanbieding is in vier dele. Die eerste deel is die Inleiding. Hierin word redes verskaf waarom investeringskoste as 'n aparte koste-item bepaal moet word ongeag die kriteria waarvolgens 'n projek beoordeel word. Die tweede deel word gewy aan die beginsels waarvolgens die sosiale geleentheidskoste (SGK) van ' $n$ padprojek bepaal word. In die derde deel word aangedui dat die kostekomponent in die SKVO van padprojekte uit twee items bestaan, naamlik die SGK van (i) die grond wat vir die padreserwe benodig word en (ii) die bou van die pad. Laasgenoemde word verdeel in die SGK van arbeid, aanleg, toerusting, brandstof, materiaal, en normale wins. Verder word ' $\mathrm{n}$ werkswyse aanbeveel om 'n finansiële projekbegroting na beraamde SGK om te skakel. Die gevolgtrekkings van die studie verskyn in die vierde deel.

\section{1}

INTRODUCTION

This article is a continuation and extension of the article 'Principles of social cost-benefit analysis of public road projects followed in South Africa' [1], which discussed the most pertinent principles that underlie the preferred social cost-benefit analysis (SCBA) methodology to evaluate public road projects in South Africa. Its main theme was the treatment of the benefit component in such SCBA, while this article focuses on the preferred approach to determine the cost component in the SCBA of road projects in South Africa [2].

Although the earliest formal exposition of the concept of SCBA was published in 1844 by the French engineer Jules Dupuit [3], the United States Flood Control Act of 1936 first formally expounded the principle that flood-control "projects should be deemed desirable if the benefits to whomsoever they may accrue are in excess of the estimated costs" [3]. The Flood Control Act offered no instructions on how to define costs and benefits. This absence of any definition has led ever since to divergent interpretations of the US legislators' intent in using the words 'costs' and 'benefits' [4]. 
A 2008 publication of the US-based Society for Benefit-Cost Analysis states: "There is no principled distinction between costs and benefits: costs can be defined as negative benefits and vice versa. Typically, however, costs are defined as the opportunity costs of the real resources expended to develop, implement and operate a program or to comply with government or other requirements, including any market impacts" (page 6) [5]. In the author's view, this lack of a uniform interpretation stems mainly from (1) a failure to realise that SCBA is a methodology applied to inform the decision-maker in the adjudication process of the measure of economic viability of possible investment projects, and that it is not simply an exercise in tallying the pros and cons of some social action; (2) ignorance about the concept of social opportunity cost; and (3) doubt about the scope of the concepts 'benefits' and 'whomsoever' as used in the Flood Control Act. The first two of these inconsistencies are addressed in this article, while the third matter was dealt with in this article's forerunner [1].

Regarding the first point above - the economic adjudication of investment projects - two modi operandi are followed internationally. One school of thought places all the supplier resources required to develop, implement, operate, and maintain a road facility in the cost category, and all user gains in the benefit category - in effect making such analysis a supplier-versus-user approach. A second school of thought, to whose premise this article subscribes, views SCBA as an analysis on behalf of society as a whole, where the road-providing authority is deemed to act on behalf of society and not only on behalf of itself. This notion is founded on the premise that, when societal transport costs rise, the road authority, functioning as society's agent, may act by investing in a resource-saving solution (paid for by road users and the taxpaying society) that curbs future ongoing road maintenance and external and user costs (also borne by road users and the tax-paying society) in excess of the cost of investment.

The modus operandi described above corresponds with the approach recommended for use in South Africa [2] - that is, to separate once-off and recurring costs in SCBA. Once-off costs represent the investment cost. In the supply of roads, investment cost represents the scarcity value of all the resources needed to implement a road facility - i.e., to complete it so that it is ready for use. Collectively, the once-off costs form the 'cost' component in SCBA. Whereas once-off costs are incurred in the initial years of the analysis period, recurring costs are incurred continuously throughout the service life of a facility. Recurring costs consist of facility user costs, facility maintenance costs, and external costs imposed on the community stemming from road operation. Recurring costs form the basis of determining the 'benefit' component in SCBA. Project benefit is equal to the difference between the recurring costs that will occur without a proposed project and the recurring costs that will accrue with it.

SCBA techniques determine the measure of benefit of a project according to two criteria: (1) net advantage, which can be determined by the net present value (NPV) technique (expressed as an absolute monetary amount); and (2) relative advantage, which is usually determined either by the benefit/cost $(\mathrm{B} / \mathrm{C})$ ratio technique or by the internal rate of return (IRR) technique (the former as a ratio and the latter as a percentage).

The definitions of these three techniques used by the Committee of Transport Officials (COTO) [2] were formulated in 2016 as follows:

"Net present value (NPV): The value obtained by subtracting the sum of a project's discounted investment costs from the sum of the discounted benefits it will achieve.

Benefit/Cost $(B / C)$ ratio: The ratio between the sum of the discounted benefits and the sum of the discounted capital (i.e. investment) costs of a project, where the value of the benefits forms the numerator and the worth of the costs forms the denominator.

Internal rate of return (IRR): The discount rate that will equalise the present worth of the investment costs of a project and the present worth of its benefits" (page 192) [6].

When a project is economically viable, (a) its NPV assumes a positive value, (b) its B/C ratio is greater than 1 , and (c) its IRR exceeds the social discount rate. Execution of a uniform SCBA methodology is a precondition for rational investment decision-making when relative advantage has to be used as a criterion: inconsistent mixing of investment cost components and negative benefits will distort the magnitude of the quotient of the $B / C$ ratio of different projects as well as the size of their IRRs. In view of the fact that the NPV technique determines the economic viability of a project on the basis of net benefit as an absolute amount, the technique does not require a systematic distinction between investment costs and negative benefits to arrive at its result. Nevertheless, NPV is the appropriate economic performance measure to select the best 
alternative among mutually exclusive projects, provided that the project's investment cost can be accommodated in the road authority's capital budget. Therefore it is clear that investment cost as a single magnitude must be identified in SCBA, regardless of the criteria according to which a project is adjudicated. Regarding the second point above - the concept of social opportunity cost - to assess the economic efficiency of the application of resources, cost-benefit analysis is based on a consideration of social cost. Social cost is the opportunity cost to society of the resources it uses. It is equal to the value of whatever society forgoes by using resources for one purpose rather than another.

Determination of the social opportunity costs (SOC; referred to as 'shadow pricing' in SCBA) of road projects forms the theme of the remainder of this four-part article. The second section deals with the nature of road investment cost, and explains the difference between financial cost and social opportunity cost. The items that are included in the 'cost' component of SCBA are explained in the third section, which also details the procedure followed to convert a detailed financial budget of road construction to a best estimate of the SOC of road investment for use in SCBA. The conclusions of the study are presented in the fourth section.

\section{THE NATURE OF ROAD INVESTMENT COST}

\subsection{General}

Investment cost is the cost of the factors of production (land, labour, capital, and entrepreneurship) that are sacrificed in the process of producing or forming capital stock. Since all economic resources are limited in supply, they all accrue some type of income for their services. The income for the use of land is rent, the income of labour is wages, the income for use of capital is interest, and the income for entrepreneurship is profits $[7,8,9,10]$.

In the context of SBCA, the SOC of the factors of production of a proposed road facility can be categorised as follows [2,11,12,13]: (a) The SOC of land refers to the economic cost of the land required to accommodate the road reserve; (b) the SOC of labour refers to the economic cost of the labour that will be used in the construction of the road facility; (c) the SOC of capital refers to the economic cost of the plant required for construction, materials, and construction vehicles and equipment, including fuel required; the proposed road facility will, once implemented, itself be a manifestation of capital formation - hence the labelling of the implementation cost of a road as its capital cost; and (d) the SOC of entrepreneurship refers to the economic cost of profit, or economic rate of return when expressed as a percentage, realisable from the construction project. The specific hurdle of the economic rate of return that must be exceeded by a road project to be economically viable is equal to the social discount rate.

Investment costs exclude maintenance costs, which form part of the operational costs of a road, which in turn form part of 'recurring costs', and are accounted for within the 'benefit' component in an SCBA as a saving. A negative saving is deducted from project benefits, and is not added to a project's cost component. The following quote from Pienaar serves as an example: "A road improvement could lead either to an increase (negative saving) or a decrease (positive saving) of some recurring cost components. Road maintenance, and probably external cost, will increase when (1) the new road is an addition to the existing network; (2) the new road replaces an old road, but is much more elaborate in size - for example, when more traffic lanes are added to a road, or a single carriageway is replaced by a dual one; and (3) there is an increase in traffic on a road. An example of obtaining a positive maintenance cost saving is by paving an unpaved road surface that suffers from the onslaught of severe and chronic rainy weather, with the result that its maintenance cost decreases" (page 132) [1].

The next four sub-sections of this section identify those components included in financial prices that do not form part of SOC. The first two of these sub-sections outline the need to apply shadow pricing, and indicate why (a) monetary transfer payments between parties within a nation and (b) sunk costs must be omitted from an SCBA. The last two sub-sections explain why facility residual value and contingencies that are included in financial budgets are excluded from the SCBA of road projects in South Africa.

\subsection{Shadow price of investment cost items}

When goods and services that appear in an SBCA are traded in a competitive market with few distortions and failures, their market prices are a relatively good guide to the willingness to pay, and they can be accepted and used in the evaluation as they stand. When they are not so traded, the economic price can be estimated directly either by finding out what people would be willing to pay if there were an effectively working market, or by taking the distorted market price and adjusting it by shadow pricing [13]. 
The shadow price of a market item is equal to its transaction price (which includes the normal profit, and not above-normal profit, that will be realised in a competitive market) minus indirect taxes and user charges, plus subsidies (whenever a good or a service is transacted below its scarcity value as a result of government intervention), along with other adjustments that take into account the effect of price distortions resulting from market failure and government regulatory failure, to represent the item's SOC. An example of this would be when, during times of widespread unemployment, the government statutorily sets minimum wage levels above the normal wage levels that would be formed by market forces.

An SCBA should be based on shadow prices, because the use of any other prices will jeopardise the objective of allocative efficiency pursued in the evaluation.

\subsection{Sunk cost}

Sunk cost is past expenditure that cannot be recovered. All items that were acquired or constructed before the SCBA of a project, and for which there is no alternative use, are fully regarded as sunk costs, since they have no recoupment value. The opportunity costs of such items are zero, and they are therefore excluded from the analysis.

The following three cases are examples of sunk expenditure in SCBA:

- Planning, traffic surveys, design, compilation, and recording of the construction details and environmental impact studies incurred prior to the time of evaluation;

- Historical road improvements and construction within the reserve of an existing road that cannot be recovered for other uses;

- $\quad$ Land already acquired and dedicated to serve as road reserve.

\subsection{Treatment of facility residual value}

Investment in road facilities is regarded as sunk because the road structure and other remnants cannot be expected to have any alternative application possibilities: first, the structure is a specialised road facility that excludes alternative use; and second, the costs of the demolition and removal of retired structures and earthworks in order to rehabilitate the site for alternative use is generally not plausible, leading to road sites that are usually simply abandoned after service-life termination [1, 2, 13]. For this reason no residual value is allocated to the existing alternative, and no residual value is projected for any proposed alternative in an SCBA.

\subsection{Best estimates and contingencies}

In an SCBA, all values that are judged to form part of the construction cost component of a proposed project ought to reflect the evaluator's best estimates of the appropriate variety, quantities, and unit costs of items, excluding additional allowances for contingencies that might be included in the financial construction budget. At the time that an SCBA is conducted, final project planning and preparation and detailed design of the analysed proposed project have not yet been finalised. Consequently, a best estimate of the variety, quantities, and unit costs of all elements that have not yet been detailed, but that will definitely occur, should be included in the SCBA as part of the proposal's investment cost. Best estimates of expenditures that will definitely occur are not subject to uncertainty, and should not be regarded as contingencies, although they are often treated as such [13].

Although additional provisions for contingencies beyond a budget compiler's best estimates - with a view to reducing the likelihood of cost overruns of a financial road construction budget - might be sensible as a business risk-mitigating strategy, such provisions should not be included in an SCBA. The reason for this is that a best estimate of the economic investment cost purports to reflect the SOC of the project, which is going to be compared with the best estimates of the SOCs of other project alternatives in the SCBA. For this reason it is imperative that the bill of quantities and financial unit prices that will be used in an SCBA be furnished by a professional quantity surveyor, approved by the road authority [2].

In the financial project planning of road construction, allowance for three types of contingencies is often made: (a) physical contingencies, (b) price contingencies, and (c) financing cost contingencies. These contingencies are briefly discussed in the paragraphs below.

Physical contingencies are discretionary provisions, in addition to the best estimates by the project budget compiler, to reduce the likelihood of cost overruns that might stem from having to use unintended alternative kinds of items or using more quantities of intended items in the execution of project 
construction than foreseen during budget compilation. In the words of Snell: "For a budget, the inclusion of a physical contingency allowance is respectable and sensible, provided that the estimate is accompanied by a clear statement of what sort of estimate it is. But for a CBA physical contingencies should not be included, because cost estimates are going to be compared with the best estimates of other parameters" (page 22) [13].

Price contingencies are precautionary provisions taken during financial planning to act against price escalation of any input prices that might lead to uncompensated construction cost overruns.

The implementation costs of a project must be adjusted as at the date of conducting the SCBA (i.e., year zero). However, in SCBA it is incorrect to make provision for cost escalation on account of inflation during the analysis period - i.e., for future years (the period beyond year zero). Based on the assumption that the relative scarcity of the resources used in the supply and operation of a facility will not change in the long run (i.e., that differential inflation will not occur), it is customary to disregard inflation in SCBA.

Financing contingencies. Interest payable on the investment amount should not be included in the SOC of a project. The way in which a project is financed has no relation to its SOC, as the alternative application possibilities of the resources actually used are the same, regardless of the method of finance.

\section{DETERMINATION OF THE SHADOW PRICE OF EACH ITEM FORMING PART OF THE INVESTMENT COST OF ROAD PROJECTS}

The shadow price of an investment in road infrastructure includes the cost of the land reserve (excluding land already acquired) plus the construction cost of the facility (excluding historical planning and design costs) - in fact, the actual scarcity value of all inputs that are still needed to complete the facility so that it is ready for use. The various components that constitute the shadow price of road construction can be classified as follows: labour, plant, equipment, fuel, materials, and normal profit. These cost items and their constituent components are discussed in the remainder of this section.

\subsection{Land cost}

The cost of the land required to provide new roads, or to widen roads, is significant, particularly in areas where land use activities are intensive and productive $[14,15]$. The cost of land that is required for future road provision and that must still be acquired must be included in SCBA. The land must be valued at the same price as land for competing uses on (1) abutting land (in the case of widening the road's land reserve) or (2) land where the road may be longitudinally extended. These points imply (1) that the opportunity cost of required land is the relevant value to use, while (2) the cost of an existing or already acquired road reserve is regarded as a sunk cost. Land cost is excluded if a project involves improvements within the reserve of an existing road.

\subsection{Facility construction costs}

The construction cost of a road facility that is to be included in an SCBA consists of future cost commitments relating to (a) direct project planning, design, and management, (b) preparation of the land reserve for development, (c) facility construction, and (c) constructor's profit. The shadow price of road construction can be determined by subdividing this cost into different homogeneous components and then converting the financial cost of each component by means of an appropriate adjustment factor to obtain its shadow price. For example, if the only transfer payment included in the financial price of a component is value added tax (VAT) at 15 per cent, its appropriate adjustment factor would be $0.8696(=1.00 / 1.15)$, and when exclusive of VAT its adjustment factor would be 1.00 (i.e., no adjustment). The following road construction components are identified: labour, plant, equipment, fuel, and materials. The shadow price adjustment for each of these components must provide for the following factors:

Labour. All labour remuneration (i.e., wages and salaries) is subject to VAT, and such tax must be subtracted to determine the shadow price of labour. The South African economy is characterised by incessantly high levels of unemployment, especially among the unskilled [16]. Surveys have shown that unskilled labour is presently remunerated at a controlled wage rate twice the amount for which unskilled labourers are willing to work [1]. The appropriate conversion factor for unskilled labour inclusive of VAT, therefore, is $0.4348(=1.00 / 1.15 \cdot 0.5)$, and exclusive of VAT its adjustment factor is $0.50(=1.00 \cdot 0.5)$.

Semi-skilled and skilled workers are at present unemployed to a lesser extent than unskilled labourers; however, these groups are not fully employed. Surveys have shown that the average remuneration of semi- 
skilled and skilled workers is at present 50 per cent more than what would have been the case during full employment and with no restrictive practices negotiated by labour and trade unions [17]. The appropriate conversion factor for semi-skilled and skilled workers inclusive of VAT, therefore, is $0.5797(=1.00 / 1.15$. $1.0 / 1.5)$, and exclusive of VAT it is $0.6667(=1.0 / 1.5)$.

Even under conditions of unemployment, the remuneration of professionals and managers must still be valued at market prices, as this labour category remains relatively scarce in such conditions [15]. The appropriate conversion factor for professionals and managers inclusive of VAT, therefore, is $1.00 / 1.15=$ 0.8696 , and exclusive of VAT its adjustment factor is 1.00 .

Surveys have indicated that the payroll amount for road construction in South Africa is split approximately as follows [6]: unskilled labour 50 per cent, semi-skilled and skilled workers 30 per cent, and professionals and managers 20 per cent. This implies that the weighted average conversion factor for labour including VAT is 0.57 , and without VAT the conversion factor for labour is 0.65 .

Plant. This component represents on-site facilities from where a project is managed and administered, and any ancillary facilities adjacent to the road being constructed. Plant also includes temporary housing, holding and storage places for equipment and materials, borrow pits, quarries, and stockpile areas [14]. Apart from VAT, materials items are generally not subject to any indirect taxation or levies [6]. The shadow price of plant can be determined from its market price, less VAT. The adjustment factor for plant including VAT, therefore, is $0.8696(=1.00 / 1.15)$, and exclusive of VAT the conversion factor for plant is 1.00 (i.e., no adjustment).

Equipment. A relatively small proportion of the equipment used in road construction in South Africa is imported. This relates to road-building equipment and specialised construction vehicles. Surveys have shown that, on a market price basis of all equipment used in local road building, imported equipment represents about 20 per cent of the total value of all equipment. Of this imported proportion, about 18 per cent consists of import duties and taxes [2]. All equipment costs are subject to VAT. The adjustment factor for equipment including VAT, therefore, is $0.843(=0.80 \cdot(1.00 / 1.15)+0.20 \cdot 1.00 / 1.18 \cdot(1.00 / 1.15))$, and without VAT the conversion factor for equipment is 0.97 .

Fuel. Surveys in the road construction industry have indicated that diesel makes up about 97.5 per cent of total fuel expenses in road building, with petrol and paraffin making up about 1.5 per cent and oil and lubricants one per cent. In view of the fact that a negligible proportion of fuel consumption in road construction is not diesel, it is recommended that the shadow price of the fuel component be regarded as the shadow price of diesel $[2,6]$.

The economic cost of fuel is established from the average bulk retail price of diesel minus transfers. The following transfers must be subtracted: fuel tax $(363.000 \mathrm{c} / \ell)$, customs and excise levy $(4.000 \mathrm{c} / \ell)$, IP tracer dye levy (aimed at preventing the mixing of diesel and paraffin) $(0.100 \mathrm{c} / \ell)$, petroleum pipelines levy $(0.330 \mathrm{c} / \mathrm{l})$, and the Road Accident Fund levy (for compensating third-party victims of accidents) $(207.000 \mathrm{c} / \ell)$. For the period 1 April 2020 to 3 September 2020, the estimated average bulk retail price of diesel in South Africa was $1209.23 \mathrm{c} / \ell$, which brings the average shadow price of diesel to $634.43 \mathrm{c} / \ell$. The adjustment factor for fuel, therefore, is $0.525(=634.43 / 1$ 209.23). Apart from the transfer payments mentioned above, the fuel is not subject to VAT [18]. Fuel sales are not subject to VAT.

Materials. Road construction materials are generally sourced locally. Apart from VAT, materials items are generally not subject to any indirect taxation or levies. The adjustment factor for materials, therefore, is $0.8696(=1.00 / 1.15)$, and without VAT the conversion factor for materials is 1.00 (i.e., no adjustment).

Total road construction cost. Analysis of the cost estimates of proposed major SANRAL road construction projects between 2002 and 2014 showed the following average relative percentages in terms of financial prices exclusive of VAT [19]: labour 21 per cent, plant 24 per cent, equipment 16 per cent, fuel 19 per cent and materials 20 per cent. Accepting these component percentages as representative of all road construction projects, and by applying the shadow price adjustment factors indicated above, a total component weighted average shadow price adjustment factor of 0.83 (before provision for normal profit) is obtained, as is shown in Table 1. To arrive at an overall shadow price adjustment factor, the total component weighted average shadow price adjustment factor needs to be inflated by the appropriate normal profit margin. Determination of the appropriate shadow profit margin to add to road construction cost is detailed in the paragraphs that follow. 
Profit. The shadow profit rate is equal to the social discount rate, as applied in the SCBA of road construction projects. Any profit margin exceeding this rate would be regarded from an allocative efficiency viewpoint as above-normal profit, while a profit margin less than this rate would not fully reflect the SOC of capital.

The social discount rate that is used in SCBA measures the value that society places on consumption that is sacrificed at present; and it is less than the discount rate of individuals acting in a market situation. This may be owing to three things: (1) society as a whole, or the government as its agent, is more aware of desirable goods and services that a free market cannot or will not provide without government incentive; (2) the ethical rights of future generations; and (3) risk. These factors are briefly described below [12, 13, $15,16,20]$.

Insufficient private investment: In many cases, investments do not benefit investors only, but also confer external benefits on parties not involved in the investment activity. The benefits of investments in public goods, quasi-public goods, and merit goods (provided by government) tend to spill over to others who are not party to the original investments, which may retard private investment if not supported by the government. Similarly, an employer that invests in the training of its own workforce would indirectly benefit other employers when its trained workers change employment. For example, employers would have little incentive to train workers if they expected them to be recruited by other employers as soon as they were trained. Whenever private investments give rise to positive externalities, it is likely that private markets will invest too little when incentives are not provided. Seen in a social perspective, this may warrant a case for policy intervention; an option would be to reduce the discount rate applied in the SCBA of public projects to a lower level than the current market interest rate.

Present and future generations: Governments are responsible for reflecting the difference between individual and societal time preferences, and also for representing the interests of future generations. This implies taking a long-term view. It is sometimes argued that society as a whole, and therefore the government as its agent, places a higher relative value on the well-being of future generations than selfinterested individuals and private entities do. A high discount rate of individuals and private entities would not be in the public interest if they perceived the remuneration of long-term savings and investments as being too low. Such a preference by the present generation is one reason why individuals generally do not demonstrate a high willingness to invest large amounts in the provision of social services and infrastructure that have long capital recovery periods before rendering positive returns. However, if the present generation as a whole placed a high value on future societal assets and prosperity, it would choose a lower present social discount rate.

Risk: Private projects are generally perceived to bear more risk than equivalent projects in the public sector. Public project risk is spread more broadly across the corps of taxpayers in the country, while the equivalent risk that private investors bear rests on the shoulders of a confined group of project owners. A higher risk premium is therefore usually incorporated into the relevant market rate of interest to capital used to finance private projects. Whereas a risk premium of about six per cent in real terms can be viewed as representative of the risk factor added to the cost of equity during investment decision-making in the private sector, a risk premium of 3.5 per cent in real terms added to the cost of long-run government bond rates has proven to be sufficient to lure private sector investment in public sector projects [20].

In his seminal work The economics of regulation: Principles and institutions, Alfred Kahn made the following revealing remark: "The conception is that there is no single, scientifically correct rate of return, but a 'zone of reasonableness,' within which judgment must be exercised. What are the limits of this zone? The bottom limit is an economic one, set by the necessity of continuing to attract capital; ..... The upper limit has been either what it was estimated capital was obtaining in investments of similar risk elsewhere or, even higher, at whatever it was deemed the traffic would bear" (page 42) [21]. The bottom and upper limits of a reasonable rate of return therefore reflect the opportunity cost of equity capital and the opportunity cost of foreign capital respectively [22].

According to Conningarth, "the social opportunity cost rate method is the rate of return to balance the social opportunity cost of undertaking the project in the public sector versus the next best alternative in the private sector where rates are observable" (page 71) [15]. The discount rate appropriate in the SCBA of public projects, which generally have a longevity of several decades, should reflect the long-run social opportunity cost of money, including societal risk. Therefore, over the life-span of a road, this rate is not affected by short-lived cyclical economic conditions. 
The South African government bond rate is an indication of the long-run opportunity cost of capital [15, 20]. The 10-year South African government bond rate during the period January 2010 to December 2019 averaged 4.55 per cent in real terms [23, 24]. Adding a risk factor of 3.5 per cent (as detailed above) to the real government bond rate yields a social rate of return of 8.05 per cent. In the light of the fact that this rate corresponds with those in the latest edition of $A$ manual for cost-benefit analysis in South Africa with specific reference to water resource development [15] and the manual Socio-economic analysis of road projects of the South African Committee of Transport Officials [2], which both recommend a social discount rate of eight per cent, this article recommends that eight per cent be retained as the appropriate social discount rate for South Africa. It is therefore recommended that the shadow profit rate for use in the SCBA of road construction projects in South Africa remain at eight per cent.

Inflating the weighted average component shadow price adjustment factors of road construction cost exclusive of VAT by the recommended normal profit margin, an overall shadow price adjustment factor of $0.90(=0.83 \cdot 1.08)$ is obtained, as detailed in Table 1 .

Table 1: Shadow price adjustment factors of road construction cost components

\begin{tabular}{|l|c|c|}
\hline $\begin{array}{l}\text { Construction cost } \\
\text { component }\end{array}$ & $\begin{array}{c}\text { Default component percentage } \\
(\%)\end{array}$ & $\begin{array}{c}\text { Shadow price adjustment factor exclusive of } \\
\text { VAT }\end{array}$ \\
\hline Labour: & 21 & 0.65 \\
All unskilled; & $0.5(21)$ & 0.50 \\
Semi-skilled and skilled; & $0.3(21)$ & 0.6667 \\
Managers and & $0.2(21)$ & 1.00 \\
professionals & 24 & 1.00 \\
\hline Plant & 16 & 0.97 \\
\hline Equipment & 19 & 0.52 \\
\hline Fuel & 20 & 1.00 \\
\hline Materials & 100 & 0.83 \\
\hline Sub-total & 0.08 & 0.07 \\
\hline Normal profit & 1.08 & 0.90 \\
\hline Profit margin factor & \multicolumn{2}{|c|}{} \\
\hline
\end{tabular}

The total shadow price of a road project (SRP) is formulated in Equation 1.

$$
S R P=L+\left(S_{l} \cdot \ell+S_{p} \cdot p+S_{e} \cdot e+S_{f} \cdot f+S_{m} \cdot m\right) \cdot 1.08
$$

Where

SRP = shadow price of the investment of a road project

$\mathrm{L}=$ cost of land still to be acquired (i.e., land cost net of historical expenditure)

$\mathrm{S}_{\ell}=$ shadow price adjustment factor of labour excluding VAT

$\ell=$ financial cost of labour component excluding VAT

$\mathrm{S}_{\mathrm{p}}=$ shadow price adjustment factor of plant excluding VAT

$\mathrm{p}$ = financial cost of plant component excluding VAT

$\mathrm{S}_{\mathrm{e}}=$ shadow price adjustment factor of equipment excluding VAT

e = financial cost of equipment component excluding VAT

$\mathrm{S}_{\mathrm{f}}=$ shadow price adjustment factor of fuel excluding VAT

$f$ = financial cost of fuel component excluding VAT

$\mathrm{S}_{\mathrm{m}}=$ shadow price adjustment factor of materials excluding VAT

$\mathrm{m}$ = financial cost of materials component excluding VAT

1.08 = profit margin factor when normal profit equals 8.0 per cent

\section{CONCLUSIONS}

Executing a uniform SCBA methodology is a precondition for rational investment decision-making when relative advantage has to be used as a criterion: inconsistent mixing of investment cost components and negative benefits will distort the magnitude of the quotient of the $\mathrm{B} / \mathrm{C}$ ratio of different projects as well as the size of their IRRs. Because the NPV technique determines the economic viability of a project on the basis of net benefit as an absolute amount, the technique does not require a systematic distinction between investment costs and negative benefits to arrive at its result. Nevertheless, NPV is the appropriate economic performance measure to select the best alternative from among mutually exclusive projects, provided that 
the project's investment cost can be accommodated in the road authority's capital budget. It is clear, therefore, that investment cost as a single magnitude must be identified regardless of the criteria according to which a project is adjudicated.

All items that have been acquired or constructed before the SCBA of a project is conducted, and for which there is no alternative use, are excluded from the analysis. The SOC of an investment in road infrastructure includes the cost of the land reserve that must still be acquired at the time that the SCBA is conducted, as well as the future construction cost of the facility. For this reason, no residual value is assigned to the existing alternative, and no residual value is projected for any proposed alternative in an SCBA.

At the time that an SCBA is conducted, final project planning and detailed design of the analysed proposed project have not yet been finalised. Consequently, a best estimate of the variety, quantities, and unit costs of all elements that have not yet been detailed, but that will definitely occur, should be included in the SCBA as part of the proposal's investment cost. Best estimates of expenditures that will definitely occur are not subject to uncertainty, and should not be regarded as contingencies.

Although making additional provision for contingencies beyond a budget compiler's best estimates with a view to reducing the likelihood of cost overruns of a financial road construction budget might be sensible as a business risk-mitigating strategy, such provisions should not be included in an SCBA. The reason for this is that a best estimate of the economic investment cost purports to reflect the SOC of the project, which is going to be compared with the best estimates of the SOCs of other project alternatives in the SCBA; they are not intended to shield against untoward financial occurrences. For this reason it is imperative that the bill of quantities and financial unit prices that will be used in an SCBA be furnished by a professional quantity surveyor, approved by the road authority.

The SOC of road construction can be determined by subdividing the construction cost into different homogeneous components and then converting the financial cost of each component by means of an appropriate shadow price adjustment factor to obtain its SOC. The various components that constitute the SOC of road construction can be classified as follows: labour, plant, equipment, fuel, materials, and normal profit.

Analysis of the cost estimates of proposed major road construction projects in South Africa showed the following average relative percentages of the construction cost components in terms of financial prices exclusive of VAT: labour 21 per cent, plant 24 per cent, equipment 16 per cent, fuel 19 per cent, and materials 20 per cent. Accepting these percentages as representative of all road construction projects, and by applying the shadow price adjustment factors (shown in Table 1), an overall weighted average shadow price adjustment factor of 0.83 (excluding VAT and before provision for normal profit) is obtained. On the basis of the research conducted, it is concluded that the normal profit rate for use in the SCBA of road construction projects in South Africa is eight per cent, which results in a shadow price adjustment factor for total road construction cost excluding VAT of $0.90(=0.83 \cdot 1.08)$.

\section{REFERENCES}

[1] Pienaar, W.J. 2018. Principles of social cost-benefit analysis of public road projects followed in South Africa. South African Journal of Industrial Engineering, 29(4):129-140.

[2] Committee of Transport Officials (COTO). 2017. Socio-economic analysis of road projects, Committee Draft CD1. Pretoria: COTO.

[3] Dupuit, J. 1844. On the measurement of the utility of public works. Annales des Ponts et Chaussées, $2^{\text {nd }}$ series, vol. 8.

[4] Pearce, D.W. 1983. The origins of cost-benefit analysis. In: Cost-benefit analysis: Studies in economics. London: Palgrave.

[5] Robinson, L.A. \& Hammitt, J.K. 2011. Behavioral economics and the conduct of benefit-cost analysis: Towards principles and standards. Journal of Benefit-Cost Analysis, 2(2):1-48.

[6] Pienaar, W.J. 2016. Regional economic assessment of the De Beers Pass Road in South Africa. South African Journal of Industrial Engineering, 27(4):182-192.

[7] Black, J. 1997. A dictionary of economics. Oxford: Oxford University Press.

[8] Greenwald, R. 1973. The McGraw-Hill dictionary of modern economics. New York: McGraw-Hill.

[9] Pearce, D.W. 1986. Macmillan dictionary of modern economics, $3^{\text {rd }}$ edition. London: Macmillan.

[10] Rutherford, D. 1992. Dictionary of economics. London: Routledge.

[11] Button, K.J. 2010. Transport economics, $3^{\text {rd }}$ edition. Cheltenham, England: Edward Elgar.

[12] Cowie, J. 2010. The economics of transport: A theoretical and applied perspective. London: Routledge.

[13] Snell, M. 1997. Cost-benefit analysis for engineers and planners. London: Thomas Telford. 
[14] South African National Roads Agency Limited (SANRAL). 2007. Land acquisition guidelines for consulting engineers. Pretoria: SANRAL.

[15] Conningarth Economists. 2014. A manual for cost-benefit analysis in South Africa with specific reference to water resource development, $3^{\text {rd }}$ edition. WRC Report K8/1044/4. Pretoria: Water Research Commission.

[16] Black, P.A., Calitz, E. \& Steenekamp, T. 2015. Public economics, $6^{\text {th }}$ edition. Cape Town: Oxford University Press.

[17] Mohr, P. 2016. Economic indicators, $5^{\text {th }}$ edition. Pretoria: Van Schaik Publishers.

[18] Department of Mineral Resources and Energy. 2020. Fuel price adjustment July 2020. http://www.energy.gov.za/files/media/fuelprice/2020/Fuel-Adjustment-July-2020.pdf [Accessed on 9 July 2020].

[19] South African National Roads Agency Limited (SANRAL). 2020. SANRAL major projects. https://www.nra.co.za/\# [Accessed on 9 July 2020].

[20] Luus, C.W. \& Mullens. D. 2008. The discount rate for cost-benefit analysis by the DBSA. Midrand: Development Bank of Southern Africa (DBSA).

[21] Kahn, A.E. 1970. The economics of regulation: Principles and institutions, Volume 1. New York: John Wiley \& Sons.

[22] Pegrum, D.F. 1973. Transportation and economics policy. Homewood, Illinois: Irwin.

[23] South African Reserve Bank. 2020. Quarterly Bulletin March 2020. Statistical tables - Capital market. https://www.resbank.co.za/Lists/News\%20and\%20Publications/Attachments/9797/05Statistical\%20tables\%20\%E2 \%80\%93\%20Capital\%20Market.pdf_[Accessed on 9 July 2020].

[24] Statista. 2020. South Africa: Inflation rate from 1984 to 2021. https://www.statista.com/statistics/370515/inflation-rate-in-south-africa/ [Accessed on 9 July 2020]. 